\title{
Pharmacokinetics of Leptin in Female Mice
}

\author{
R. A. HART ${ }^{1}$, R. C. DOBOS ${ }^{2}$, L. L. AGNEW ${ }^{1}$, R. L. TELLAM ${ }^{3}$, J. R. MCFARLANE ${ }^{1}$ \\ ${ }^{1}$ Centre for Bioactive Discovery in Health and Ageing, University of New England, Armidale, \\ NSW, Australia, ${ }^{2} \mathrm{NSW}$ Department of Primary Industries, Armidale, NSW, Australia, ${ }^{3} \mathrm{CSIRO}$ \\ Tropical Animal Production/Livestock Industries, Brisbane, QLD, Australia
}

Received April 10, 2015

Accepted June 26, 2015

On-line October 8, 2015

\begin{abstract}
Summary
Pharmacokinetics of leptin in mammals has received limited attention and only one study has examined more than two time points and this was in $o b / o b$ mice. This study is the first to observe the distribution of leptin over a time course in female mice. A physiologic dose (12 ng) of radiolabelled leptin was injected in adult female mice via the lateral tail vein and tissues were dissected out and measured for radioactivity over a time course up to two hours. Major targets for administered leptin included the liver, kidneys, gastrointestinal tract and the skin while the lungs had high concentrations of administered leptin per gram of tissue. Leptin was also found to enter the lumen of the digestive tract intact from the plasma. Very little of the dose $(<1 \%)$ was recovered from the brain at any time. Consequently we confirm that the brain is not a major target for leptin from the periphery, although it may be very sensitive to leptin that does get to the hypothalamus. Several of the major targets (GI tract, skin and lungs) for leptin form the interface for the body with the environment, and given the ability of leptin to modulate immune function, this may represent a priming effect for tissues to respond to damage and infection.
\end{abstract}

\section{Key words}

Leptin • Distribution • Pharmacokinetics • Elimination • Periphery

\section{Corresponding author}

J. McFarlane, University of New England, Armidale, NSW 2351, Australia. E-mail: jmcfarla@une.edu.au

\section{Introduction}

Leptin is a $16 \mathrm{kDa}$ cytokine originally identified as a hormone secreted from adipose tissue (Zhang et al.
1994) but is also known to be synthesized in other tissues including the placenta (Masuzaki et al. 1997), skeletal muscle (Wang et al. 1998) and the stomach (Bado et al. 1998). Leptin circulates at concentrations that correlate with fat mass (Considine et al. 1996) and signals via its alternately spliced receptors (Lee et al. 1996), notably LepRb, which has the greatest signaling capacity (Bjørbæk et al. 1997). Animals that lack functional leptin, $o b / o b$, or LepRb, $d b / d b$, express a phenotype of voracious appetite and obesity and correction of the deficit corrects this (Campfield et al. 1995, de Luca et al. 2005, Halaas et al. 1995, Kowalski et al. 2001, Pelleymounter et al. 1995, Weigle et al. 1995). Furthermore, LepRb has been found to be expressed in the hypothalamus at high density in nuclei thought to regulate energy balance (Chen et al. 1996, Lee et al. 1996). Consequently, leptin was hypothesized to signal information from the periphery to the brain about energy stored as fat (Friedman and Halaas 1998).

In addition to leptins central effects it is increasingly being recognized as having roles in the periphery, which include regulating aspects of reproduction, immune function, energy substrate preference and regulation of nutrient absorption. During reproduction, leptin attenuates testosterone secretion (Tena-Sempere et al. 1999) and prepares the endometrium for embryo implantation (Malik et al. 2001), it is involved in regulating immune responses (Loffreda et al. 1998) and may be involved in the development of visceral obesity (Duffield et al. 2009). In muscle leptin has been reported to induce a preference for fatty acids as a fuel substrate (Muoio et al. 1997), while in the digestive tract leptin increases the activity of 
glucose transporters (GLUT) 2 and 5 (Pearson et al. 2001, Sakar et al. 2009), reduces the activity of sodiumglucose cotransporter (SGLT) 1 (Ducroc et al. 2005, Iñigo et al. 2007) and has been postulated to regulate the gut microbiome by altering the secretion of anti-microbial proteins in the colon (Rajala et al. 2014).

Despite the wealth of literature about leptin, most papers describing leptin distribution have focused on local movement, e.g. transport across the blood brain barrier (Banks et al. 1996) or kidneys (Cumin et al. 1996), rather than a broad examination of leptin distribution. Indeed, to date the authors are aware of only five pharmacokinetic studies, with four of these having examined leptin distribution from the circulation (Ceccarini et al. 2009, Hill et al. 1998, Li et al. 2013, McMurty et al. 2004, Van Heek et al. 1996). In chickens a time course study has been conducted (McMurty et al. 2004), whereas in mammals only one study has reported tissue distribution at more than two time points for comparison in a number of tissues, however this examined distribution in $o b / o b$ mice at a supraphysiologic dose via intraperitoneal administration (Van Heek et al. 1996). The locations of leptin binding in the periphery of 'normal' animals after a physiologic dose over a time course are largely unknown. Therefore, a time course experiment may provide detailed information about major targets for peripheral leptin and its profile in the target tissues. Here we describe the distribution of radiolabelled leptin at a physiologic dose over a two hour time period in female mice following intravenous administration.

\section{Materials and Methods}

\section{Animals}

Female Swiss mice, aged 8-16 weeks weighing $37.92 \pm 2.33 \mathrm{~g}$, were obtained from a colony maintained at the University of New England Animal House. Mice were kept in same sex litter groups with ad libitum access to commercial chow and water. A $12 \mathrm{~h}$ light dark cycle was maintained with lights on at 07:00 $\mathrm{h}$ AEST in a room kept at $22 \pm 0.5^{\circ} \mathrm{C}$. All work was approved by the University of New England Animal Ethics Committee and conformed to the NHMRC Code of Practice for the Care and Use of Animals for Scientific Purposes.

\section{Experimental protocol}

Recombinant bovine leptin (Kauter et al. 2000) was labelled with ${ }^{125}$ Iodine (ANSTO, Lucas Heights,
NSW, Australia) using the Iodogen method (Thermo Fisher Scientific, Rockford, IL). Mice were injected via the lateral tail vein with $12 \mathrm{ng}$ of radiolabelled leptin $(37.02 \mathrm{kBq})$ in a total volume of $100 \mu \mathrm{l}$ made up with phosphate buffered solution. Animals were then placed in an individual cage with access to food and water until the specified time when the animal was euthanized by $\mathrm{CO}_{2}$ asphyxiation at 5, 15, 30, $60(\mathrm{n}=2 \mathrm{each})$ and $120 \mathrm{~min}$ $(n=1)$ after injection to observe the radiolabelled leptin distribution over time.

Tissues were dissected and weighed, with duplicate samples placed in polypropylene tubes and measured for total $\gamma$-radioactivity (1470 Wizard, Perkin Elmer, Turku, Finland). Background radiation was subtracted from all samples. Measurements from replicates were averaged and multiplied across the total mass of the relevant tissue to calculate total tissue accumulation.

Cardiac puncture was performed immediately after euthanasia to collect blood, which was transferred into a heparinized tube before organs were dissected out and weighed. The digestive tract tissues were measured with their respective contents. Two samples of small intestine contents were precipitated with $30 \%$ trichloroacetic acid to determine intactness of the radiolabelled leptin. Skin was removed with the exception of that around the snout and 'cuffs' around the paws and tail of the animals. Four segments (fore limb, hind limb, interscapular region and dorsal cervical region) were collected, with radioactivity measured and averaged for these samples. This average was then multiplied for the mass of the whole skin to estimate the total recovered from the tissue. Similarly for the blood, duplicate samples of blood were measured and this was averaged and multiplied to estimate the total in circulation based on a total blood volume estimated at $96.3 \mathrm{ml} / \mathrm{kg}$ of body weight as previously reported (Riches et al. 1973).

\section{Data analysis}

Plasma and whole body clearance of leptin was calculated by using the area under the curve method, fitting a second order exponential decay curve to the respective data using Origin 4.10 (Microcal Software Inc. 1996) using the formula:

$$
y=A e^{-x / t_{1}}+B e^{-x / t_{2}}
$$

where $\mathrm{y}$ represents the radioactivity per $\mathrm{ml}$ of blood or 
total radioactivity recovered from the body at time $\mathrm{x}$ (min), A and B are the radioactivity present in each pool and $t_{1}$ is $1 / \alpha$ and $t_{2}$ is $1 / \beta$ where $\alpha$ and $\beta$ are the decay constants for the respective pools.

All data are expressed as mean \pm standard error, unless raw data are presented.

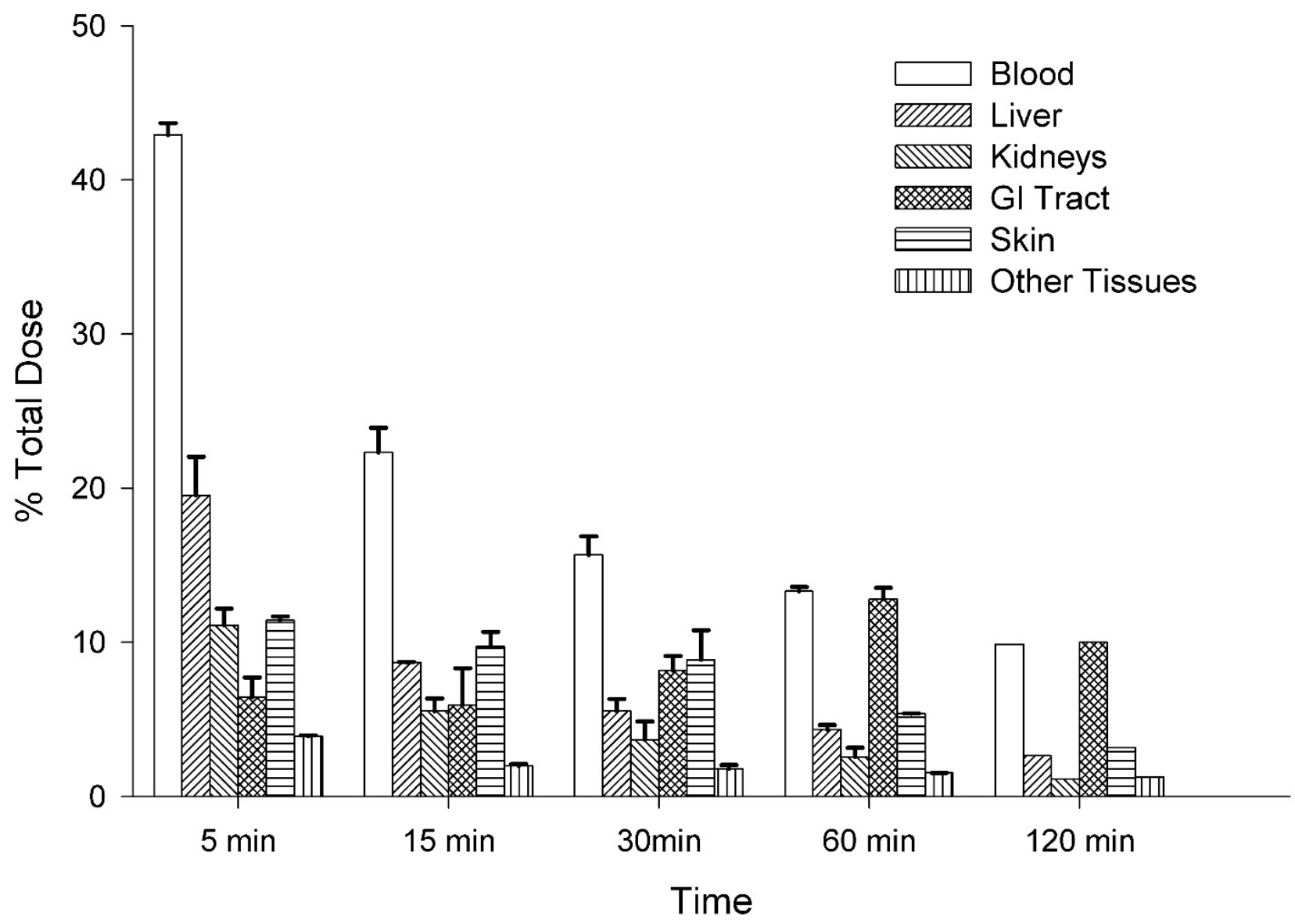

Fig. 1. Major targets for leptin in female mice after intravenous administration as the percentage of initial dose recovered from each tissue (GI Tract - gastrointestinal tract and contents; Other Tissues - pooled data for brain, submandibular salivary glands, spleen, heart, lungs, ovaries, uterus and perirenal fat).

\section{Results}

After intravenous administration of leptin to female mice at a physiologic dose, major targets were the liver, kidneys, digestive tract and skin. Radiolabelled leptin was recovered from other tissues and these were pooled as "other tissues". These tissues included the brain, submandibular salivary glands, spleen, heart, lungs, ovaries, uterus and perirenal fat (Fig. 1).

Radiolabelled leptin from the blood, liver, kidneys and the pooled 'other tissues' was rapidly cleared and was cleared from the skin slightly slower. Five minutes post-injection the blood contained $42.9 \pm 0.8 \%$ of the administered dose, the liver $19.5 \pm 2.5 \%$, the kidneys $11.1 \pm 1.1 \%$, skin $11.4 \pm 0.3 \%$ and 'other tissues' $3.9 \pm 0.1 \%$ of the administered dose. The lungs contributed $19-33 \%$ of the radiolabelled leptin recovered in the 'other tissues' over the duration of the experiment. In contrast, between 5 and $60 \mathrm{~min}$ following administration the total radiolabelled leptin recovered from the digestive tract (pooled with luminal contents) increased from $6.4 \pm 1.3 \%$ of the dose to $12.8 \pm 0.7 \%$ of the dose before a slight decrease to $10.0 \%$ of the dose $120 \mathrm{~min}$ after injection. The contents of the small intestine $(n=2)$ were found to be $45.2 \pm 1.6 \%$ intact. The highest amount of radiolabelled leptin recovered from the brain was $0.267 \%$ of the dose 5 min after administration (data not shown).

The total amount of radiolabelled leptin recovered from all examined tissues followed an exponential decay pattern (Fig. 2). A total of $95.3 \pm 5.9 \%$ of the administered dose was recovered $5 \mathrm{~min}$ 
post-injection, declining to $54.3 \pm 4.1 \% 15 \mathrm{~min}$ postinjection and decreasing to $28.1 \%$ of the dose $120 \mathrm{~min}$ after administration. Using these data whole body leptin kinetics were examined, revealing administered leptin had a clearance rate of $0.23 \mathrm{ml} / \mathrm{min} / \mathrm{kg}$ and a half-life of $47.3 \mathrm{~min}$ (Table 1) in the whole animal with an $\alpha$ phase half-life of $3.6 \mathrm{~min}$ and a $\beta$ phase half-life of $150.0 \mathrm{~min}$.

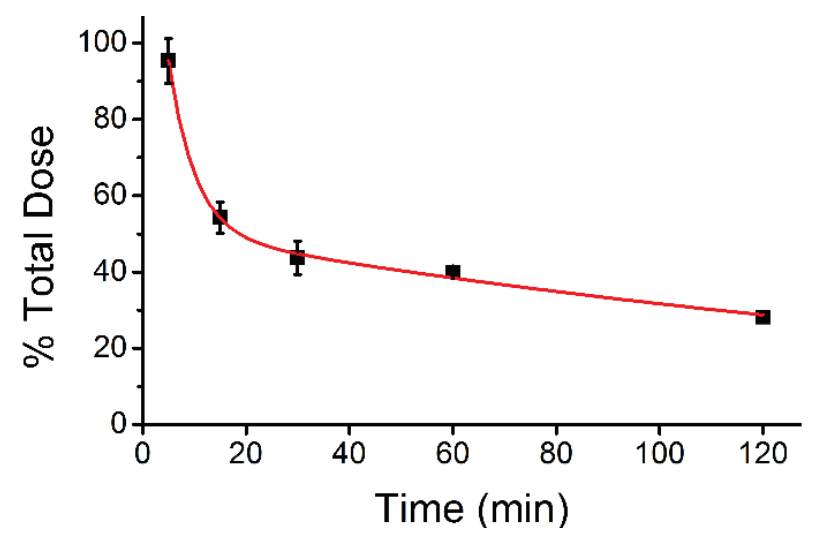

Fig. 2. Radiolabelled leptin clearance from all examined tissues of female mice following intravenous administration presented as percentage of total administered dose with a second order exponential decay curve fit.

Table 1. Radiolabelled leptin pharmacokinetic parameters in female mice.

\begin{tabular}{lcc}
\hline & Plasma & Whole Body \\
\hline $\begin{array}{l}\text { Clearance Rate } \\
\text { (ml/kg/min) }\end{array}$ & 1.59 & 0.23 \\
Half-Life (min) & 32.0 & 47.3 \\
\hline
\end{tabular}

Radiolabelled leptin recovered from the blood rapidly dropped from $14.01 \pm 0.38 \%$ of the administered dose per $\mathrm{ml}$ (dose $/ \mathrm{ml}$ ) $5 \mathrm{~min}$ post-injection to $5.28 \pm 0.94 \%$ of dose $/ \mathrm{ml} 15 \mathrm{~min}$ after administration. Following this a slower decline was seen to $3.09 \%$ of dose/ml 120 min post-injection (Fig. 3). Using these data the plasma clearance rate was calculated to be $1.58 \mathrm{ml} / \mathrm{kg} / \mathrm{min}$ and the half-life of administered leptin in the plasma to be $32 \mathrm{~min}$ (Table 1) with an $\alpha$ phase halflife of $2.9 \mathrm{~min}$ and a $\beta$ phase half-life of $230.1 \mathrm{~min}$.

In most of the tissues examined the radiolabelled leptin per gram of tissue (dose/g) decreased over the course of the experiment. Five minutes after injection concentrations in the kidneys and liver contained $22.71 \pm 3.70 \%$ of dose $/ \mathrm{g}$ and $10.19 \pm 1.34 \%$ of dose $/ \mathrm{g}$, respectively, while the skin had $2.54 \pm 0.10 \%$ of dose $/ g$.
In the lungs a rapid drop was seen 5-15 min after administration from $7.69 \pm 0.49 \%$ of dose $/ g$ to $2.45 \pm 0.45 \%$ of $\mathrm{dose} / \mathrm{g}$; this then remained relatively stable until 60 min post-injection, followed by a drop $120 \mathrm{~min}$ after injection to $1.46 \%$ of dose $/ \mathrm{g}$. In the brain there was also a decrease in exogenous leptin per gram 5-30 min post-injection from $0.55 \pm 0.05 \%$ of dose/g to $0.15 \pm 0.02 \%$ of dose $/ g$, followed by a slight increase $60 \mathrm{~min}$ post-injection to $0.19 \pm 0.03 \%$ of dose $/ \mathrm{g}$ and then a slight decrease $120 \mathrm{~min}$ after administration to $0.11 \%$ of dose/g. Radiolabelled leptin recovered per gram of perirenal fat $5 \mathrm{~min}$ after administration was $3.55 \pm 0.10 \%$ of dose/g, dropping to approximately $0.74 \%$ of dose $/ g$, which was maintained to $60 \mathrm{~min}$ post-injection before decreasing to $0.51 \%$ of dose/g 120 min post-injection. Muscle from the left quadriceps and biceps femoris were examined 15, 30 and 60 min post-injection $(n=1$ animal each) and were found to have $0.67 \%$ of dose $/ g, 0.62 \%$ of dose $/ g$ and $0.43 \%$ of dose/g, respectively.

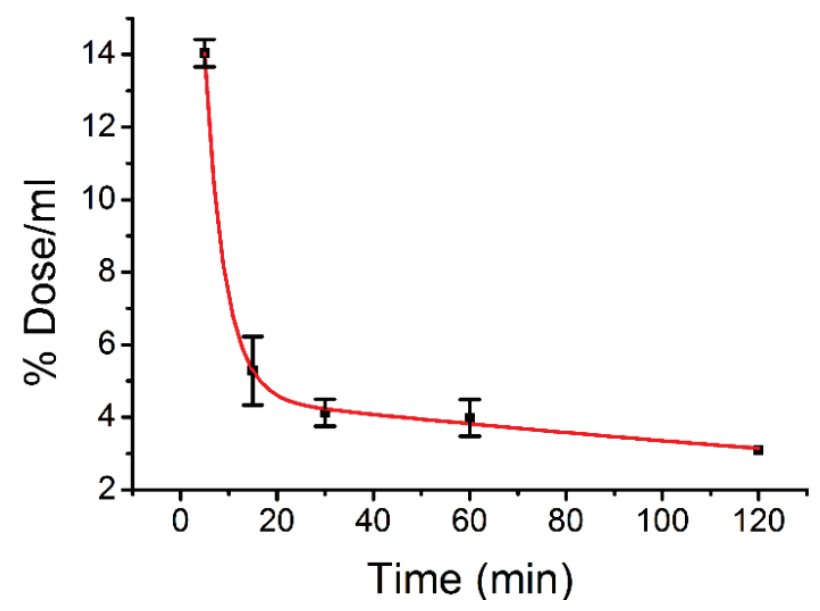

Fig. 3. Radiolabelled leptin in the blood of female mice after intravenous administration measured as percentage of dose per $\mathrm{ml}$ with a second order exponential decay curve fit.

Generally, when radiolabelled leptin per gram of tissue was examined the pattern was similar to that reported in total dose recovery above, with highest concentrations recovered from the blood (Fig. 3), kidneys, liver, skin and perirenal fat (Fig. 4) and a decrease in radioactivity detected. One notable difference was that the lungs displayed a high amount of radiolabelled leptin per gram.

\section{Discussion}

Leptin distribution was examined in female mice after intravenous injection of a physiologic dose of 
radiolabelled leptin. The tissue distribution of radiolabelled leptin reported is similar in pattern to those reported previously for intravenous administration in rats (Hill et al. 1998) and chickens (McMurty et al. 2004) and following intraperitoneal administration in mice (Van Heek et al. 1996). The tissues where a high amount of radiolabelled leptin was recovered included the, kidneys, liver, skin and gastrointestinal tract (and contents).
Similar to the previous studies, it was found that the brain was not a major target for leptin in these mice. In most of the tissues examined there appeared to be an initial rapid clearance of leptin from the tissue before a slower phase of clearance. The radiolabelled leptin was detected in all examined tissues up to the conclusion of the experiment $120 \mathrm{~min}$ after the injection.
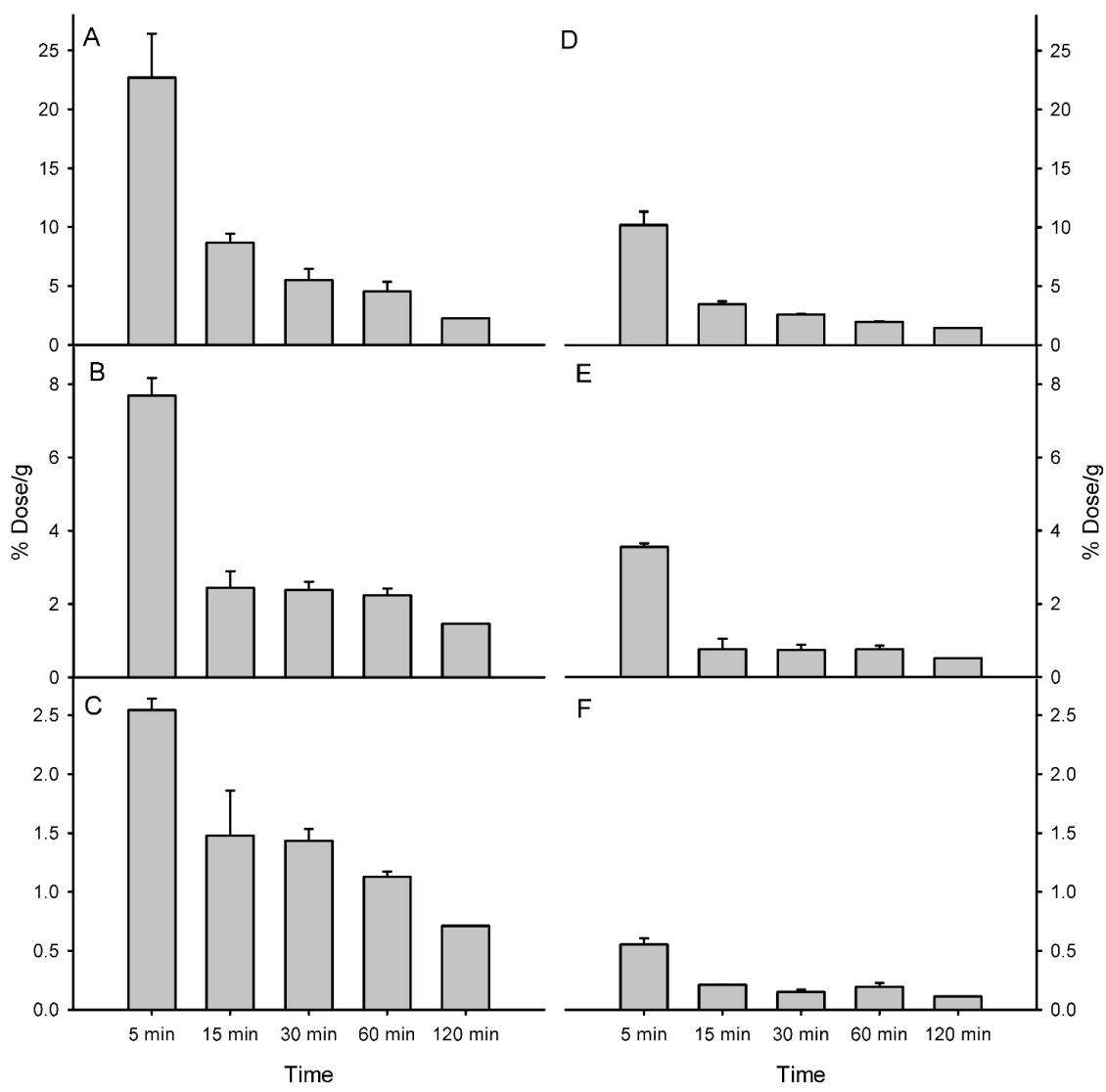

Fig. 4. Radiolabelled leptin after intravenous administration to female mice presented as percentage of administered dose per gram of tissue (A - Kidneys; B - Lungs; C - Skin; D Liver; $\mathrm{E}-$ Perirenal fat; $\mathrm{F}-$ Brain).
Consistent with previous reports in several vertebrates (Hill et al. 1998, McMurty et al. 2004, Van Heek et al. 1996), very little of the administered leptin ( $<1 \%$ of the administered dose here) was detected in the brain of the mice over the duration of the experiment. While on face value this may seem to contradict the notion of leptin from the periphery playing a major role in the central nervous system in the regulation of energy turnover and body mass (Friedman and Halaas 1998), it must be noted that LepRb is found in the hypothalamus at relatively high density compared with most other regions of the brain (Ghilardi et al. 1996, Lee et al. 1996), particularly in the arcuate, ventromedial, dorsomedial, lateral and paraventricular nuclei, which are thought to be involved in appetite regulation (Fei et al. 1997, Mercer et al. 1996). Furthermore, intravenously administered radiolabelled leptin, albeit at a supraphysiologic dose, can be recovered from the arcuate nucleus of the hypothalamus and the choroid plexus (Banks et al. 1996). This may indicate that these hypothalamic nuclei are extremely sensitive to the signaling of leptin from the periphery, which may be supported by the intravenous and intraperitoneal administration of leptin to mice inducing STAT3 activation in the hypothalamus at a physiologic dose (Vaisse et al. 1996). However, as $>99 \%$ of the administered dose of leptin was not recovered from the central nervous system it would appear that the major roles for leptin lie in the periphery.

The total administered leptin recovered from the mice declined over the course of the experiment. This is consistent with leptin being eliminated from the system via the kidneys (Cumin et al. 1996), but also suggests that 
leptin may also enter tissues that were not sampled here. As $4.68-71.92 \%$ of the administered dose was unaccounted for over the duration of the experiment some representative samples of muscle were examined. In female mice skeletal muscle has been reported to account for $20 \%$ of body mass (Griffin and Goldspink 1979), if this were assumed and that $0.6 \%$ of the dose was recovered per gram of muscle (an approximation of the findings) there may be $4.55 \%$ of the dose in skeletal muscle over the entire animal. Both muscle (De Matteis et al. 1998, Hoggard et al. 1997, Löllmann et al. 1997) and bone (osteoblasts and chondrocytes) express leptin receptors (Steppan et al. 2000). In the muscle leptin attenuates insulin induced lipogenesis (Muoio et al. 1997) and stimulates fuel oxidation (Dulloo et al. 2002, Muoio et al. 1997). In bone leptin has been shown to stimulate growth in ob/ob mice (Steppan et al. 2000), although centrally it appears to inhibit bone growth (Ducy et al. 2000). Therefore, it seems reasonable to speculate that a portion of the leptin not recovered over the course of the experiments was sequestered into the musculoskeletal system.

The plasma half-life for the administered leptin in the plasma was found to be $32 \mathrm{~min}$. This is comparable with reported endogenous human leptin half-life, at $24.9 \mathrm{~min}$ (Klein et al. 1996). The a phase half-life, $2.9 \mathrm{~min}$, is similar to reports in rats of approximately $5.1 \mathrm{~min}$ (Zeng et al. 1997) and $3.4 \mathrm{~min}$ (Hill et al. 1998), less than reported for human leptin in monkeys at 10.4 min (Ahrén et al. 2000) and intermediate to the early phase half-lives $(1.2-7.2 \mathrm{~min})$ reported in rats in a third order model (Cumin et al. 1996). In contrast, the terminal phase plasma half-life was $230.1 \mathrm{~min}$ and is much higher than the values reported in mice (Ahrén et al. 2000) and rats (Zeng et al. 1997) of approximately $49 \mathrm{~min}$, or other reported values in rats ranging from $71 \mathrm{~min}$ (Hill et al. 1998) to $90 \mathrm{~min}$ (Cumin et al. 1996) and is also higher than that reported for human leptin in rhesus monkeys of 96 min (Ahrén et al. 2000). However, a number of these studies were performed at pharmacologic doses ranging from $0.25 \mathrm{mg} / \mathrm{kg}$ (Cumin et al. 1996) to $10 \mathrm{mg} / \mathrm{kg}$ (Ahrén et al. 2000). The clearance from the blood reported is consistent with leptin removal by the kidneys, as has been identified as the primary mechanism of elimination (Cumin et al. 1996, 1997). The reported data may have been improved if the experiment was run over a longer period with more early time points, which may have enabled the fitting of a third order exponential decay curve, as reported previously (Cumin et al. 1996). Due to the sexual dimorphism of circulating leptin concentrations (Saad et al. 1997) it may be interesting to determine whether the parameters examined here are similar in male mice.

Interestingly, the whole body half-life for administered leptin was approximately 1.5 times longer than that for plasma borne leptin at $47.3 \mathrm{~min}$, the reason for this is not clear. However, as hypothesized previously (Hill et al. 1998) there seems to be a large pool of more slowly cleared leptin that is thought to include leptin bound to receptors in tissues of the periphery. As indicated earlier, the musculoskeletal system appears to be a target for leptin. Additionally, adipose tissue may retain some peripheral leptin, although this may be transient, as indicated by the rapid drop in concentration seen in the perirenal fat. Another large sink for circulating leptin was identified in the digestive tract, with $12.8 \%$ of the administered dose recovered $60 \mathrm{~min}$ after administration. This, as well as the slow clearance from the blood 15-120 min after administration may indicate that leptin enters these tissues for a period of time before re-entering the circulation. This possibility is supported by the finding that LepRa-d facilitate the endocytosis and subsequent exocytosis of intact leptin from cells in vitro (Tu et al. 2007). Further investigation would be needed to confirm this possibility.

Generally the pattern in total leptin recovery and leptin per gram in tissues examined followed a similar pattern, with a notable exception in the lungs. The highest total recovery detected from the lungs was $1.3 \pm 0.01 \%$ of the administered dose $5 \mathrm{~min}$ post-injection (data not shown), in comparison $>10 \%$ of the radiolabelled leptin administered was recovered from the blood, liver, kidneys, skin and digestive tract, respectively, at various times observed. However, when concentration was examined $5 \mathrm{~min}$ post-injection $7.69 \pm 0.49 \%$ of dose $/ \mathrm{g}$ was recovered from the lungs and only the blood, liver and kidneys exhibited higher amounts per ml or gram. It is possible that a portion of the radiolabelled leptin recovered from the lungs is actually in the blood, however cardiac puncture would be expected to have removed most of this and the data presented are consistent with distribution reported in rats (Hill et al. 1998). This would seem to suggest that leptin plays a particularly important role in the lungs. Leptin receptor mRNA is found at a relatively high abundance in the lungs (Ghilardi et al. 1996, Löllmann et al. 1997) and both long and short isoforms are expressed as proteins in the tissue, with immunohistochemistry showing club 
cells, muscle and veins stain strongly for LepRb (De Matteis et al. 1998). Furthermore, leptin has been shown to have physiologic effects in the lungs including regulation of tissue maturation and possibly increasing surfactant secretion (Kirwin et al. 2006). Radiolabelled leptin concentrations were apparently maintained at approximately $2.36 \%$ dose $/ g$ for $45 \mathrm{~min}$ during the experiment, possibly indicating that leptin has a normal maintenance role in the lungs and as LepRb is expressed in club cells (De Matteis et al. 1998), which can modulate inflammation (Snyder et al. 2010), this may be related to immune function.

The total recovery of exogenous leptin from the skin was examined for the first time and showed that the skin is a major target for circulating leptin. Five min postinjection $11.4 \pm 0.3 \%$ of the radiolabelled leptin was detected in the skin. It should be noted that skin was removed intact from animals with some underlying tissue and may therefore also be a proxy for subcutaneous fat, as leptin is known to accumulate in fat (Ceccarini et al. 2009, Li et al. 2013). However, as the skin is the largest organ of the body, it seems reasonable to suggest that with such a high recovery of the administered dose from the tissue that this could be the skin itself. In support of this LepRb is expressed in human fibroblasts (Glasow et al. 2001). Leptin is capable of stimulating skin growth and enhances wound healing, with LepRb expression reported at the margins of wound sites (Frank et al. 2000). Furthermore, leptin has been found in the skin and is reduced in response to injury (Stallmeyer et al. 2001), coupled with the high proportion of leptin recovered from the skin here, leptin appears to play a role in the maintenance of skin homeostasis. As a high concentration of leptin was also found in the lungs and large amounts were in the digestive tract, all tissues that constitute the interface of the body with the environment, it may be that leptin primes these tissues ready to respond to insult, but more work would be required to confirm this.

In summary, plasma leptin half-life in female mice was found to be shorter than whole body half-life and is presumed to be due to accumulation of leptin in peripheral tissues. A total of $12.8 \%$ of the dose was found to be in the digestive tract tissues and contents $60 \mathrm{~min}$ after administration, while $11.4 \%$ was recovered from the skin $5 \mathrm{~min}$ after administration, representing major targets for leptin in the circulation and possibly indicating far more prominent roles for leptin in these tissues. A larger sample size and longer time course may allow the use of more complex modelling, such as the use of a third order exponential decay curve, to accurately describe leptin pharmacokinetics in the female mouse.

\section{Conflict of Interest}

There is no conflict of interest.

\section{Acknowledgements}

RAH was the recipient of an Australian Postgraduate Award and a UNE Strategic Top-up Grant.

\section{References}

AHRÉN B, BALDWIN RM, HAVEL PJ: Pharmacokinetics of human leptin in mice and rhesus monkeys. Int $J$ Obes Relat Metab Disord 24: 1579-1585, 2000.

BADO A, LEVASSEUR S, ATTOUB S, KERMORGANT S, LAIGNEAU J-P, BORTOLUZZI M-N, MOIZO L, LEHY T, GUERRE-MILLO M, LE MARCHAND-BRUSTEL Y, LEWIN M: The stomach is a source of leptin. Nature 394: 790-793, 1998.

BANKS W, KASTIN A, HUANG W, JASPAN J, MANESS L: Leptin enters the brain by a saturable system independent of insulin. Peptides 17: 305-311, 1996.

BJØRBÆK C, UOTANI S, DA SILVA B, FLIER J: Divergent signaling capacities of the long and short isoforms of the leptin receptor. J Biol Chem 272: 32686-32695, 1997.

CAMPFIELD L, SMITH F, GUISEZ Y, DEVOS R, BURN P: Recombinant mouse OB protein: evidence for a peripheral signal linking adiposity and central neural networks. Science 269: 546-549, 1995.

CECCARINI G, FLAVELL RR, BUTELMAN ER, SYNAN M, WILLNOW TE, BAR-DAGAN M, GOLDSMITH SJ, KREEK MJ, KOTHARI P, VALLABHAJOSULA S, MUIR TW, FRIEDMAN J: PET Imaging of leptin biodistribution and metabolism in rodents and primates. Cell Metab 10: 148-159, 2009.

CHEN H, CHARLAT O, TARTAGLIA L, WOOLF E, WENG X, ELLIS S, LAKEY N, CULPEPPER J, MORE K, BREIBART R, DUYK G, TEPPER R, MORGENSTERN J: Evidence that the diabetes gene encodes the leptin receptor: identification of a mutation in the leptin receptor gene in $\mathrm{db} / \mathrm{db}$ mice. Cell 84: 491-495, 1996. 
CONSIDINE R, SINHA M, HEIMAN M, KRIAUCIUNAS A, STEPHENS T, NYCE M, OHANNESIAN J, MARCO C, MCKEE L, BAUER T, CARO J: Serum immunoreactive-leptin concentrations in normal-weight and obese humans. N Engl J Med 334: 292-295, 1996.

CUMIN F, BAUM H-P, LEVENS N: Leptin is cleared from the circulation primarily by the kidney. Int J Obes Relat Metab Disord 20: 1120-1126, 1996.

CUMIN F, BAUM H-P, LEVENS N: Mechanism of leptin removal from the circulation by the kidney. $J$ Endocrinol 155: 577-585, 1997.

DE LUCA C, KOWALSKI TJ, ZHANG Y, ELMQUIST JK, LEE C, KILIMANN MW, LUDWIG T, LIU S-M, CHUA SC Jr: Complete rescue of obesity, diabetes, and infertility in $\mathrm{db} / \mathrm{db}$ mice by neuron-specific LEPR-B transgenes. J Clin Invest 115: 3484-3493, 2005.

DE MATTEIS R, DASHTIPOUR K, OGNIBENE A, CINTI S: Localization of leptin receptor splice variants in mouse peripheral tissues by immunohistochemistry. Proc Nutr Soc 57: 441-448, 1998.

DUCROC R, GUILMEAU S, AKASBI K, DEVAUD H, BUYSE M, BADO A: Luminal leptin induces rapid inhibition of active intestinal absorption of glucose mediated by sodium-glucose cotransporter 1. Diabetes 54: 348-354, 2005.

DUCY P, AMLING M, TAKEDA S, PRIEMEL M, SCHILLING A, BEIL F, SHEN J, VINSON C, RUEGER J, KARSENTY G: Leptin inhibits bone formation through a hypothalamic relay: a central control of bone mass. Cell 100: 197-207, 2000.

DUFFIELD JA, VUOCOLO T, TELLAM R, MCFARLANE JR, KAUTER KG, MUHLHAUSLER BS, MCMILLEN IC: Intrauterine growth restriction and the sex specific programming of leptin and peroxisome proliferatoractivated receptor $\gamma$ (PPAR $\gamma$ ) mRNA expression in visceral fat in the lamb. Pediatr Res 66: 59-65, 2009.

DULLOO A, STOCK M, SOLINAS G, BOSS O, MONTANI J-P, SEYDOUX J: Leptin directly stimulates thermogenesis in skeletal muscle. FEBS Lett 515: 109-113, 2002.

FEI H, OKANO H, LI C, LEE G-H, ZHAO C, DARNELL R, FRIEDMAN J: Anatomic localization of alternatively spliced leptin receptors (Ob-R) in mouse brain and other tissues. Proc Natl Acad Sci U S A 94: 7001-7005, 1997.

FRANK S, STALLMEYER B, KÄMPFER H, KOLB N, PFEILSCHIFTER J: Leptin enhances wound reepithelialization and constitutes a direct function of leptin in skin repair. J Clin Invest 106: 501-509, 2000.

FRIEDMAN J, HALAAS J: Leptin and the regulation of body weight in mammals. Nature 395: 763-770, 1998.

GHILARDI N, ZIEGLER S, WIENSTNER A, SOFFEL R, HEIM M, SKODA R: Defective STAT signaling by the leptin receptor in diabetic mice. Proc Natl Acad Sci U S A. 93: 6231-6235, 1996.

GLASOW A, KIESS W, ANDEREGG U, BERTHOLD A, BOTTNER A, KRATZSCH J: Expression of leptin (Ob) and leptin receptor (Ob-R) in human fibroblasts: regulation of leptin secretion by insulin. J Clin Endocrinol Metab 86: 4472-4479, 2001.

GRIFFIN G, GOLDSPINK G: The increase in skeletal muscle mass in male and female mice. Anat Rec 177: 465-470, 1979.

HALAAS J, GAJIWALA K, MAFFEI M, COHEN S, CHAIT B, RABINOWITZ D, LALLONE R, BURLEY S, FRIEDMAN J: Weight-reducing effects of the plasma protein encoded by the obese gene. Science 269: 543546, 1995.

HILL R, MARGETIC S, PEGG G, GAZZOLA C: Leptin: its pharmacokinetics and tissue distribution. Int J Obes 22: 765-770, 1998.

HOGGARD N, MERCER J, RAYNER D, MOAR K, TRAYHURN P, WILLIAMS L: Localization of leptin receptor mRNA splice variants in murine peripheral tissues by RT-PCR an in situ hybridization. Biochem Biophys Res Commun 232: 383-387, 1997.

IÑIGO C, PATEL N, KELLETT G, BARBER A, LOSTAO M: Luminal leptin inhibits intestinal sugar absorption in vivo. Acta Physiol (Oxf) 190: 303-310, 2007.

KIRWIN S, BHANDARI V, DIMATTEO D, BARONE C, JOHNSON L, PAUL S, SPITZER A, CHANDER A, HASSINK S, FUNANAGE V: Leptin enhances lung maturity in the fetal rat. Pediatr Res 60: 200-204, 2006.

KLEIN S, COPPACK SW, MOHAMED-ALI V, LANDT M: Adipose tissue leptin production and plasma leptin kinetics in humans. Diabetes 45: 984-987, 1996. 
KOWALSKI T, LIU S-M, LEIBEL R, CHUA S Jr: Transgenic complementation of leptin-receptor deficiency. I. Rescue of the obesity/diabetes phenotype of LEPR-null mice expressing a LEPR-B transgene. Diabetes 50: 425-435, 2001.

LEE G-H, PROENCA R, MONTEZ J, CARROL K, DARVISHZADEH J, LEE J, FRIEDMAN J: Abnormal splicing of the leptin receptor in diabetic mice. Nature 379: 632-635, 1996.

LI Z, CECCARINI G, EISENSTEIN M, TAN K, FRIEDMAN J: Phenotypic effects of an induced mutation of the ObRa isoform of the leptin receptor. Mol Metab 2: 364-375, 2013.

LOFFREDA S, YANG S, LIN H, KARP C, BRENGMAN M, WANG D, KLEIN A, BULKLEY G, BAO C, NOBLE P, LANE M, DIEHL A: Leptin regulates proinflammatory immune responses. FASEB $J$ 12: 57-65, 1998.

LÖLLMANN B, GRÜNINGER S, STRICKER-KRONGRAD A, CHIESI M: Detection and quantification of the leptin receptor splice variants Ob-Ra, b, and, e in different mouse tissues. Biochem Biophys Res Commun 238: 648652, 1997.

MALIK N, CARTER N, MURRAY J, SCARAMUZZI R, WILSON C, STOCK M: Leptin requirement for conception, implantation, and gestation in the mouse. Endocrinology 142: 5198-5202, 2001.

MASUZAKI H, OGAWA Y, SAGAWA N, HOSODA K, MATSUMOTO T, MISE H, NISHIMURA H, YOSHIMASA Y, TANAKA I, MORI T, NAKAO K: Nonadipose tissue production of leptin: leptin as a novel placenta-derived hormone in humans. Nat Med 3: 1029-1033, 1997.

MCMURTY J, ASHWELL C, BROCHT D, CAPERNA T: Plasma clearance and tissue distribution of radiolabelled leptin in the chicken. Comp Biochem Physiol A Comp Physiol 138: 27-32, 2004.

MERCER J, HOGGARD N, WILLIAMS L, LAWRENCE C, HANNAH L, TRAYHURN P: Localization of leptin receptor mRNA and the long form splice variant $(\mathrm{Ob}-\mathrm{Rb})$ in mouse hypothalamus and adjacent brain regions by in situ hybridization. FEBS Lett 387: 113-116, 1996.

MUOIO D, DOHN G, FIEDOREK F Jr, TAPSCOTT E, COLEMAN R: Leptin directly alters lipid partitioning in skeletal muscle. Diabetes 46: 1360-1363, 1997.

PEARSON P, O'CONNOR D, SCHWARTZ M: Novel effect of leptin on small intestine adaptation. J Surg Res 97: 192-195, 2001.

PELLEYMOUNTER M, CULLEN M, BAKER M, HECHT R, WINTERS D, BOONE T, COLLINS F: Effects of the obese gene product on body weight regulation in Ob/Ob mice. Science 269: 540-543, 1995.

RAJALA MW, PATTERSON CM, OPP JS, FOLTIN SK, YOUNG VB, MYERS M Jr: Leptin acts independently of food intake to modulate gut microbial composition in male mice. Endocrinology 155: 748-757, 2014.

RICHES A, SHARP J, BRYNMOR THOMAS D, VAUGHAN SMITH S: Blood determination in the mouse. J Physiol 228: 279-284, 1973.

SAAD M, DAMANI S, GINGERICH R, RIAD-GABRIEL M, KHAN A, BOYADJIAN R, JINAGOUDA S, EL-TAWIL K, RUDE R, KAMDAR V: Sexual dimorphism in plasma leptin concentration. $J$ Clin Endocrinol Metab 82: 579-584, 1997.

SAKAR Y, NAZARET CL, LETTÉRON P, AIT OMAR A, AVENATI M, VIOLLET B, DUCROC R, BADO A: Positive regulatory control loop between gut leptin and intestinal GLUT2/GLUT5 transporters links to hepatic metabolic functions in rodents. PLoS One 4: e7935, 2009.

SNYDER J, REYNOLDS S, HOLLINGSWORTH J, LI Z, KAMINSKI N, STRIPP B: Clara cells attenuate the inflammatory response through regulation of macrophage behaviour. Am J Respir Cell Mol Biol 45: 161-171, 2010.

STALLMEYER B, KÄMPFER H, PODDA M, KAUFMANN R, PFEILSCHIFTER J, FRANK S: A novel keratinocyte mitogen: regulation of leptin and its functional receptor in skin repair. J Invest Dermatol 117: 98-105, 2001.

STEPPAN CM, CRAWFORD DT, CHIDSEY-FRINK KL, KE H, SWICK AG: Leptin is a potent stimulator of bone growth in ob/ob mice. Regul Pept 92: 73-78, 2000.

TENA-SEMPERE M, PINILLA L, GONZÁLEZ L, DIÉGUEZ C, CASANUEVA F, AGUILAR E: Leptin inhibits testosterone secretion from adult rat testis in vitro. J Endocrinol 161: 211-218, 1999.

TU H, PAN W, FEUCHT L, KASTIN A: Convergent trafficking pattern of leptin after endocytosis mediated by ObRaObRd. J Cell Physiol 212: 215-222, 2007. 
VAISSE C, HALAAS J, HORVATH C, DARNELL J Jr, STOFFEL M, FRIEDMAN J: Leptin activation of Stat3 in the hypothalamus of wild-type and $o b / o b$ mice but not $d b / d b$ mice. Nat Genet 14: 95-97, 1996.

VAN HEEK M, MULLINS D, WIRTH M, GRAZIANO M, FAWZI A, COMPTON D, FRANCE C, HOOS L, CASALE R, SYBERTZ E, STRADER C, DAVIS H Jr: The relationship of tissue localization, distribution and turnover to feeding after intraperitoneal ${ }^{125}$ I-leptin administration to $o b / o b$ and $\mathrm{db} / \mathrm{db}$ mice. Horm Metab Res 28: 653-658, 1996.

WANG J, LIU R, HAWKINS M, BARZILAI N, ROSETTI L: A nutrient-sensing pathway regulates leptin gene expression in muscle and fat. Nature 393: 684-688, 1998.

WEIGLE DS, BUKOWSKI T, FOSTER D, HOLDERMAN S, KRAMER J, LASSER G, LOFTON-DAY C, PRUNKARD D, RAYMOND C, KUIJPER JL: Recombinant $o b$ protein reduces feeding and body weight in the $o b / o b$ mouse. J Clin Invest 96: 2065-2070, 1995.

ZENG J, PATTERSON B, KLEIN S, MARTIN D, DAGOGO-JACK S, KOHRT W, MILLER S, LANDT M: Whole body leptin kinetics and renal metabolism in vivo. Am J Physiol 273: E1102-E1106, 1997.

ZHANG Y, PROENCA R, MAFFEI M, BARONE M, LEOPOLD L, FRIEDMAN J: Positional cloning of the mouse obese gene and its human homologue. Nature 372: 425-432, 1994. 